Ethics, law, and the junior doctor

\author{
$\boldsymbol{V}$ \\ Daniel Sokol, ${ }^{1}$ Len Doyal, ${ }^{2}$ Lesley Doyal ${ }^{3}$ \\ CHOICE
}

For teachers of medical ethics and law, teaching junior doctors is particularly interesting for a number of reasons. First, it reveals starkly the variability in ethical knowledge among doctors. One junior doctor may see no ethical or legal issue in a presented case while another will immediately identify three or four such problems. Second, once the issues are recognised, most junior doctors are in our experience all too happy to discuss, sometimes passionately, instances of ethical and even legal violations from their own experiences. Ethics and law, which may have seemed a dry and irrelevant subject to them at medical school, can be suddenly transformed into a practical discipline that has a direct clinical impact on their professional lives. Third, such discussions highlight the potential disjunction between what is taught to undergraduates and graduates about ethics and law and what happens in 'real' life, prompting reflection on how to improve this teaching to make it as useful and relevant as possible.

\section{ETHICS AND LAW IN THEORY AND PRACTICE}

Although the teaching of ethics and law varies widely within medical education, in many instances there is sadly so little curriculum time given to the subject that teachers can teach no more than the bare essentials. This may partly explain the apparent disjunction between theory and practice-exploring how to reconcile the two requires more teaching time than is generally available.

Unfortunately, not all teachers of medical ethics and law have the opportunity to teach junior doctors and thus not all can obtain the insights derived from doing so. These teachers will derive much benefit from the paper in this issue by Catherine Quarini, a Core Training year 1 doctor. ${ }^{1}$ So too will those junior doctors who suggest

\footnotetext{
${ }^{1}$ Imperial College London, London, UK; ${ }^{2}$ Queen Mary University of London, London, UK; ${ }^{3}$ Bristol University, Bristol, UK

Correspondence to Dr Daniel Sokol, Department of Primary Care and Public Health, Charing Cross Campus, Imperial College London, London W6 8RF, UK; daniel.sokol@talk21.com
}

that they have not yet encountered any ethical problems, a claim as disconcerting as an admission of unrecognised clinical incompetence. This vivid and frank account should also be compulsory reading for students approaching the end of their undergraduate training and for more senior doctors who may have qualified in the days where there was no formal ethics and legal education. Several of the ethical and legal improprieties outlined in the article are committed by registrars and consultants, and their insensitivity to the issues raised by the author clearly creates problems for the junior doctors, who are left to pick up the pieces. Should they do or say anything about these violations when the time available is as short as the consultant's temper, and they believe that the all important reference for their next job may be affected? Quarini's article highlights the pervasiveness of ethical and legal issues in the ordinary day of a junior doctor and confirms the importance of preparing medical students to address these challenges once they qualify.

\section{SOME COMMON ETHICAL AND LEGAL DILEMMAS}

Such is the style of her article, the reader feels like a voyeur, invited into the secret world of the junior doctor, standing over the narrator's shoulder and witnessing: the curt and dismissive attitude of the consultant with a patient in the ward round; the misleading introduction of a medical student as a "colleague who needs to examine your heart"; the dubious consent obtained for the photograph of a patient's arthritic hand; the realisation that the consultant ordered a scan for the wrong patient; the tactical misrepresentation of a patient's condition to convince the radiologist to perform a CT and MRI scans promptly; and a string of other ethical and legal issues too numerous to mention here.

The issues raised are not those that hit the headlines in the national press. There are no ears on mice, no sperm artificially created from stem cells, no inadvertent intrathecal and lethal injection of vincristine, no allocation decisions about scarce ventilators in a swine flu pandemic. The issues are nonetheless real and problem- atic, calling for more or less immediate decisions. Unlike in medical school where students may be asked to ponder on an ethico-legal issue for several days, even weeks, here there is no luxury of time. Doing nothing will not avoid the problem for that too is an action open to moral and legal evaluation.

So now that Quarini has pointed out the ubiquity of ethical and legal problems in the life of a junior doctor, what next? In our experience, clinicians are not thrilled when ethicists provide a rambling list of reasons why an act may be morally acceptable then proceed to list another set of reasons for why this same act may be morally unacceptable and why an alternative may be morally preferable. It is not infrequently of the form "on the one hand....on the other...". The clinician, hearing this monologue, may well think "Yes, but what do I do?". In our view, it is inappropriate for a medical ethicist or a clinician with some ethical and legal training to attempt to provide guidance through embarking on a long, confusing ethical or legal analysis that yields no feasible answer. Clinicians facing such problems will be rightly frustrated, all the more so if time is pressing. However, it is also irresponsible to provide black-andwhite answers devoid of any explanation for the decision ("Do this."). If asked, the ethicist should provide guidance if he or she feels competent to provide it, but the rationale for the decision should also be communicated, even if only briefly. This helps the clinician understand and evaluate the advice, and encourages him or her to ask questions and, if desired, to engage in debate. It also fulfils an educational purpose for any medical students and junior doctors who happen to be present.

\section{THE IMPORTANCE OF TRANSPARENCY}

Quarini specifies the scope of the aim in the article at the outset. She does not attempt to resolve the problems but is concerned with highlighting their existence. That process of making the hidden explicit is, as she notes, the first step towards a resolution. The second step is finding solutions through thinking and reasoning about the issues. Here, there may be an important advisory role for medical ethicists, but unless they are medically qualified themselves, this will usually be limited by their lack of clinical knowledge and experience of the realities and practicalities of practising medicine near the bottom of the hospital hierarchy. Again, many such experiences 
remain veiled in secrecy, at least outside the profession. It is clearly difficult to appreciate what it is like to be a junior doctor without having gone through the experiences oneself; even if one has, it is easy to forget some of the pressures and compromises encountered at the time. The experiences of junior doctors do not remain constant through the ages.

How much do consultants really understand the challenges faced by junior doctors? Undoubtedly, some senior doctors will struggle to understand fully the circumstances of contemporary junior doctors. Although there are similarities, the situation today-including the expectations and demographics of junior doctors themselves - is in many ways different to what it was like for junior doctors in years past. Many jobs are more competitive than ever. The pressure to publish and present at conferences is strong.

\section{WHAT SHOULD BE DONE?}

Quarini's article is an invitation for junior doctors, as a group, to play a more important role in the search for solutions to the ethico-legal problems she has raised. In their editorial, Levy and Coward point to the importance of formal education, discussion, and encouragement to address these ethical issues. ${ }^{2}$ These steps are clearly desirable, but they do not necessarily lead to moral action. There is a world of difference between discussing ethical problems in the relative safety of a seminar, meeting, or an interview and actually acting ethically, where the implications suddenly become real. No doubt many junior doctors, and indeed senior doctors, who witness ethical violations keep quiet, even if they know that the 'right' answer in an interview would be to address the problem head on. However, we know of several conscientious junior doctors who have refused to accept the status quo and written letters to their Trust, informing them of the dangerously low staff levels and the impact this may have on the welfare of patients and staff. There is a fear of reprisals, of the potential of old-fashioned consultants tut-tutting and recalling the time when they had to work 6 weeks continuously without sleep, food or drink, hopping on one leg and reciting the BNF from memory.

Recent research in medical education suggests that medical students are reluctant to whistleblow and it would not be surprising if the same were true for junior doctors. ${ }^{3}$ Yet understandable fears of reprisals can be reduced if the response is collective (there is safety in numbers), and Trusts should consider how to facilitate such a response in the context of balancing the inexperience of juniors with the potential insensitivities of seniors. Some Trusts have followed suit and the BMA has given helpful advice to junior doctors about whistleblowing which in itself offers a degree of protection from reprisal. ${ }^{4}{ }^{5}$ If junior doctors do not get involved in improving their lot, others run the risk of making ill-judged decisions for them, however well-intentioned they may be.

It has not been our intention to paint a gloomy picture of the ethico-legal climate in which junior doctors work, although there can be little doubt that problems do persist and are in some instances endemic. 6 Many of the more senior clinicians will observe that the climate has, in many ways, much improved since their day as a junior. Yet responsible doctors of whatever grade will hope to improve it still further and will want to see an end to the ethico-legal problems that Quarini illustrates in her article. This will require a collective and coordinated effort to look at the systemic factors that contribute to the emergence of these problems. ${ }^{7}$ The challenge is finding how to address them in a manner that is constructive, effective, and that does not require martyrdom on anyone's part.

We hope that readers who have experienced similar problems to those outlined by Dr Quarini, or who think that these problems may have been exaggerated or underplayed, will contact us at the $P M J$ to initiate further discussion and debate about these important questions.

\section{Competing interests None.}

Provenance and peer review Commissioned; not externally peer reviewed.

Postgrad Med J 2010;86:629-630.

doi:10.1136/pgmj.2009.092635

\section{REFERENCES}

1. Quarini C. A day in the life of a junior doctor: everyday ethic encounters. Postgrad Med $\mathrm{J}$ 2010;86:632-35

2. Levy J, Coward R. Ethical dilemmas: a focus of discussion for junior doctors. Postgrad Med $J$ 2010;86:631.

3. Rennie S, Crosby J. Students' perceptions of whistle blowing: implications for self-regulation. A questionnaire and focus group survey. Med Educ 2002;36:173-9.

4. http://www.ekhut.nhs.uk/home-page/for-staff/a-zdepartments/human-resources/employment-matters/ whistleblowing-procedure/.

5. British Medical Association. Whistleblowing Advice for BMA Members Working in NHS Secondary Care About Raising Concerns in the Workplace. London: BMA, 2009. http://www.bma.org.uk/ images/Whistleblowing_tcm41-156406.pdf.

6. http://www.epolitix.com/latestnews/article-detail/ newsarticle/nhs-culture-discourages-whistleblowing/.

7. Reason J. Human error: models and management. $B M$ J 2000;320:768-70. 